\section{Our genetic legacy}

\section{Christopher Wills}

The Language of the Genes: Biology, History and the Evolutionary Future. By Steve Jones. HarperCollins: 1993. Pp. 251. £16.99. To be published in the United States later this year by Doubleday.

THIS book is an expansion of the Reith lectures that the geneticist Steve Jones gave on British Broadcasting Corporation radio in 1991 . It was with some bemusement that I realized that substantial numbers of people in England still sit down and listen, for tens of minutes at a time, while somebody intelligent and witty talks about something complicated and interesting on the radio. No commercials destroy the speaker's flow of thought, and he does not have to field telephone calls from people who in the course of the programme have found martians under their beds. What heaven for somebody with the academic's urge to inform without being interrupted.

Jones rises to the occasion. The book is urbane and casts its net widely, covering topics from the probable genetic evolution of our species through the complexities of human sociobiology to the promises and perils of genetic engineering. He says many eminently sensible things along the way, and I am sure that the listeners to his lectures ended up with a broad appreciation of the complexities of human genetics and evolution.

The two form, as Jones makes plain, a seamless whole. Our genome is enormously complex, and our understanding of how it operates to produce adult humans is growing apace. Only a part of this understanding will come from the Human Genome Project, for our genes cannot be comprehended except in their evolutionary context. Jones exhibits the biologist's distrust of Big Science when he bemoans the shift of research funds into "... Programs, Institutes and Centers [that] give the predictable new life at the expense of the unexpected". And indeed much of the book, except when it briefly discusses such megaprojects as the search for the cystic fibrosis gene, is a celebration of the thousands of cases in which small science has illuminated some fascinating aspect of how we work and how we have evolved. And often he peeks into areas that cry out for a more thorough exploration. One that particularly caught my attention was the old and unpleasant eugenic idea of anticipation, in which eugenicists bemoaned the fact that genetic defects such as myotonic dystrophy seemed to get worse as one generation succeeded the next. It now turns out that our understanding of a number of diseases

\title{
The Green movement
}

GreEN's functions, to many young mathematics students, seem to be plucked out of thin air to solve second-order differential equations. The same could almost be said of their inventor. George Green (1793-1841) came from a far from mathematical background, working as a miller in Notting ham until he reached his thirties, and had little formal education in his youth. Despite this, his formidable mathematical achieve-

ments made

him one of the pioneers of nineteenth century math. ematical physics. The lack of recognition that he received in his lifetime is simply in the best traditions of all pioneers.

The Green's function technique formu. lated in his first and most important publication, the Essay on the Application of Mathematical Analysis to the Theories of Electricity and Magnetism, has become a staple of classical physics and quantum mechanical calculations. Nuclear physics, quantum electrodynamics and radar all owe something to Green. And Green's Theorem, which transforms tricky prob. lems of summation over volume to (one hopes) more tractable problems in terms of area, is familiar to most physicists. But had it not been for the interest of the young William Thomson, later Lord Kelvin, the work might have been lost. Thomson

- fragile X syndrome, myotonic dystrophy, spinobulbar muscular atrophy and most recently Huntington's disease has provided a molecular explanation for anticipation. The eugenicists, repellent though their conclusions might have been, were at least right about the phenomenon. This subject alone deserves a whole book.

In such a wide-ranging book there are inevitably some places where there is room for disagreement. Jones says: "A chimp may share ninety-eight per cent of its genes with a typical human being but it is certainly not ninety-eight per cent human: it is not human at all - it is a chimp". Actually, a chimpanzee shares essentially 100 per cent of its genes with a human - it is small details of many of those genes that are different. And there are far more similarities between chimps and humans than there are differences - we do, after all, have 99.8 per cent of our evolutionary history in common. I also think that Jones rather slights the contribution of palaeontologists to our understanding of human evolution, though he is clever in doing so: "If geography is about maps and biogra- came across a reference to the ingenious Essay by Mr Green of Nottingham" in 1845 , when he had just reached the end of his undergraduate career and was eager to embark on research in electricity and magnetism. He scoured the Cambridge bookshops without suc. cess, but a chance meeting with his tutor on the eve of his departure for Paris finally put a copy in his possession.

The rest, as they say, is history. The subsequent stir caused among the French mathematical community, the essay's second publication and the integration of Green's ideas into mainstream physical science, are brought to life in a new biography by D. M. Cannell, timed to coincide with the bicentenary (George Green, Mathematician and Physicist 1793-1841: The Background to his Life and Work, Athlone, London, £35, \$70). Celebrations for the bicentenary on 14 July may lift Green from his present obscurity. Next week, in addition to lectures at Nottingham University and the Royal Society in London, a memorial (above) will be dedicated to Green in Westminster Abbey, as will a stained glass window in Gonville and Caius College, Cambridge, where Green began a belated mathematics degree at the age of 40 , five years after publishing the Essay.

L.M.

phy about chaps, human paleontology is mainly about gaps". While palaeontologists have sometimes been overenthusiastic in interpreting their remarkable discoveries, they have still told us far more about our prehistory than all the molecular family trees in our genomes could ever do.

Finally, Jones suggests that because of the recent relaxation of selective pressures on at least part of our species, "we are as near to our biological Utopia as we are ever likely to get". I hope we are, but I doubt it. As the popular T-shirt says, "Malthus was right!". We cannot multiply indefinitely and savage the planet as we are doing without the evolutionary chickens eventually coming home to roost. Still, this intelligent and informative book deserves to be read widely, since it provides a vivid demonstration of what a remarkable and fragile product of evolution our species is.

Christopher Wills is in the Department of Biology, University of California, San Diego, La Jolla, California 92093, USA. 